\title{
Utilization of Pine Fruit and Peanut Shell Wastes into Briquettes as an Alternative Fuel
}

\author{
Mohamad Mirwa *, Muhammad Abdus Salam Jawwad \\ Department of Environmental Engineering, University of Pembangunan Nasional "Veteran” Jawa Timur, Indonesia
}

\begin{abstract}
Fuel or energy sources scarcity is currently a problem in Indonesia. Pine waste and peanut shells are wastes that have potential to be processed into alternative energy as briquettes, using molasses as adhesive. Briquette was made by destroying the material into small pieces that have been carbonized and sieved with a variation of 20 and 30 mesh size, added with molasses, and then molded with a hydraulic press. Briquettes are dried using an oven at $105^{\circ} \mathrm{C}$ for 10 hours to remove moisture content. The pine to peanut shell ratio used are of $0: 1,1: 0,1: 1,1: 2,1: 3,2: 1,2: 3,3: 1$ and $3: 2$. The analysis includes analysis of calorific value, moisture content, ash content and compressive strength. The result shows the pine waste to peanut shells ratio of 1:0 has the highest calorific value for 20 mesh is $4674.50 \mathrm{Cal} / \mathrm{g}$ and for 30 mesh is $4585.10 \mathrm{Cal} / \mathrm{g}$. The lowest water content for 20 mesh is $1.76 \%$ and for 30 mesh is $1.85 \%$. The lowest ash content for 20 mesh is $0.58 \%$ and for 30 mesh is $0.59 \%$. And the highest compressive strength for 20 mesh is $35.20 \mathrm{~kg} / \mathrm{cm}^{2}$ and for 30 mesh is $28.90 \mathrm{~kg} / \mathrm{cm}^{2}$.
\end{abstract}

Keyword: Energy Alternative, Briquettes, Utilization

\section{Introduction}

One of the big problems faced by Indonesia today is the scarcity of energy fuel, which become emergently crucial due to the raise of population in Indonesia. Energy is mostly consumed to people daily transportation facilities and industrial activities in addition to the needs of economic and social activities on a household scale. The more depleted the amount of fossil fuels, the impact is starting to be felt nowadays, as a can be seen the amount of kerosene is getting limited. For this reason, renewable energy sources are needed in providing sustainable energy sources. This will be even more so if the raw materials for alternative energy sources come from waste, so that it can reduce production costs and reduce the negative effects of waste accumulation on the environment [1].

One of the alternative energy source options is biomass energy. Biomass energy is an alternative energy source that needs to be prioritized in its development compared to other energy sources. On the other hand, Indonesia as an agricultural country produces a lot of agricultural waste that is not utilized yet. The agricultural waste can be processed into an artificial solid fuel that is used as a substitute for alternative fuels called briquettes. Making briquettes with different compositions of mixed materials (agricultural waste) will affect the absorption of water content, ash content and the quality of the resulting calorific value [2].

Pine (Pinus merkusii) is a very common plant that can be found in hilly and mountainous areas. The fruit of the pine tree fell a lot near the pine tree. Current utilization of pine fruit waste processed into a product or material for art accessories is still not optimal, because there has not been optimal effort with the utilization of pine fruit waste, which underlies the reason for utilizing the waste, besides that it can reduce waste. Many previous researches revealed that pine fruit can be used as a good ingredient to make a briquetts. From the results of a study, it was found that a pine fruit briquette has a moisture content of $8.66 \%$, calorific value $5,489.5 \mathrm{Cal} / \mathrm{g}, 73.90 \%$ bound carbon, $22.90 \%$ volatile matter and $3.20 \%$ ash content [3].

Other than pine, peanut is also a very common plant in Indonesian with very high production. After being consumed, the peanut shell is usually thrown away and not processed for further usage. However, peanut shells have potential to be used as an energy resource. If the peanut shell is used as fuel for briquettes as an alternative to fossil fuels, it will provide many benefits. Not only is it more environmentally friendly than fossil fuels, but also as an alternative fuel that can be a priority that must be developed to overcome the depletion of fossil fuels. As a cultivated plant, peanuts are mainly harvested for their seeds which are rich in protein and fat. In addition to harvesting the seeds, people usually use peanuts, the leaves and stems are also harvested for animal feed or as green manure. Peanut shells that are forgotten by many people are reprocessed into useful goods. Peanut shell chemical properties Peanut shell ash content is $5.3 \%$ $7.3 \%$. The moisture content of peanut shells is on average $4.95 \%-7.75 \%$ The calorific value of peanut shells in the form of raw materials is $4,344 \mathrm{kcal} / \mathrm{kg}$ while the calorific

\footnotetext{
* Corresponding author : mmirwan.t1@upnjatim.ac.id
} 
value of peanut shell briquettes is $4,201.01-4,640.44$ $\mathrm{Kcal} / \mathrm{kg}$ [4].

This research was aimed to recycle and utilize biomass waste as an alternative energy source to be used in Indonesia. Pine fruit and peanut shells as the main ingredients will be used to make briquettes with a mixture of molasses as adhesive. To examine quality of the briquettes, analysis of calorific value, moisture content, ash content and compressive strength will be applied.

\section{Methods}

\subsection{Materials}

1. Pine fruit waste was taken from Ngliman Village, Sawahan District, Nganjuk Regency.

2. Peanut shells were taken from Prambon Market, Prambon District, Sidoarjo Regency.

3. Sugar cane (molasses) as an adhesive for the briquettes.

\subsection{Tools}

1. Cylindrical mold with a diameter of $6 \mathrm{~cm}$ and a height of $5 \mathrm{~cm}$

2. Sieve size 20 mesh and 30 mesh

3. Furnaces

4. Desicator

5. Oven

6. Press tool

7. Dimples

8. Pounder

9. Baking pan

10. Basin

11. Digital scales

\subsection{Procedure}

The process carried out in the production of briquettes is described as follows:

1. Raw Material Preparation

The raw materials prepared are pine fruit waste and peanut shells. These materials are collected and cleaned of useless materials. After that, the waste of pine fruit and peanut shells is dried in the sun for 1-2 days to dry.

2. Carbonization Process

The waste material of pine fruit and peanut shells are then carbonized. The waste material of pine fruit and peanut shells was ground to make the particle size smaller, after that it was put in a furnace for the carbonization process at a temperature of $450{ }^{\circ} \mathrm{C}$ for 60 minutes. Then the material is put into a desiccator, waiting for the temperature to cooling down (room temperature), then the carbonized pine fruit and peanut shell waste material is sieved through a sieve.

3. Size Measurement

The size of the material is reduced by using a mortar. The results of the reduced material were sieved using a 20 mesh sieve and 30 mesh for pine fruit waste and peanut shells.

4. Ratio Determination

The material that has been shieved and then mixed with the ratio as treatment, namely:

a. Comparison of pine fruit waste : peanut shell $=0$ $: 1$

b. $\quad$ Comparison of pine fruit waste: peanut shell $=1$ : 0

c. Comparison of pine fruit waste: peanut shell $=1$ $: 1$

d. $\quad$ Comparison of pine fruit waste: peanut shell $=1$ :

e. $\quad$ Comparison of pine fruit waste: peanut shell $=1$ : 3

f. Comparison of pine fruit waste : peanut shell $=2$ $: 1$

g. Comparison of pine fruit waste: peanut shell $=2$ : 3

h. Comparison of pine fruit waste: peanut shell $=3$ $: 1$

i. $\quad$ Comparison of pine fruit waste: peanut shell $=3$ : 2

5. Molding Process

a. Prepare a cylindrical mold from a gutter pipe or iron pipe with a diameter of $6 \mathrm{~cm}$ and a height of $5 \mathrm{~cm}$.

b. Mixing waste pine fruit and peanut shells with molasses (molasses).

c. Enter the mixture of pine nut waste, peanut shells and adhesive that has been mixed well into the mold.

d. The mixture is printed in the mold using a hydraulic press in the form of a jack.

e. Remove the briquettes from the mold then place on the baking sheet.

f. Oven at $105^{\circ} \mathrm{C}$ for 10 hours to remove moisture content in briquettes.

g. After finishing in the oven, the briquettes were cooled in a desiccator for 15 minutes.

h. The briquettes are ready to be tested based on the research parameters.

6. Drying

The prints were dried in an oven with a temperature of $105^{\circ} \mathrm{C}$ for 10 hours, the aim was to reduce the water content of the briquettes, so that the briquettes burned quickly and did not smoke. Too high a temperature can cause the mold to crack.

\section{Results and Discussion}

This study was aimed to examine the effect of raw materials for waste pine fruit and peanut shells on moisture content, ash content, calorific value and compressive strength produced by briquettes. From these raw materials, comparison treatment was carried out and with variations of 20 mesh and 30 mesh sieves. Meanwhile, the temperature of the carbonization process and the amount of adhesive used were determined without varying the treatment. The discussion of the research conducted is as follows: 


\subsection{Effect of Treatment Composition on Water Content}

Water content analysis is used to determine the water content contained in the briquettes. This analysis was carried out by heating the briquette sample in an oven at $105^{\circ} \mathrm{C}$. Water will evaporate at a temperature of $100^{\circ} \mathrm{C}$, so it is estimated that at a temperature of $105^{\circ} \mathrm{C}$ the water contained in the briquettes will be completely evaporated. The time required for drying the moisture content is 10 hours[5].

From the data analysis, it can be seen that the hypothesis in this study is that the more addition of pine fruit waste, the lower the water content. Vice versa, the more the addition of peanut shells, the water content will increase. This is because pine fruit waste has less water than peanut shells.

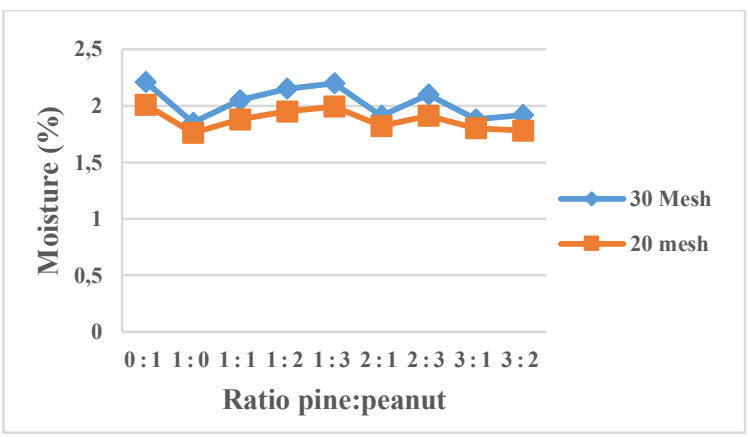

Fig. 1. Relationship between Comparison of Materials with Moisture Content (\%)

In Figure 1. it can be seen that the water content of the research briquettes has met the standards set, namely SNI 4931:2010[6]. The entire moisture content of the briquettes is on average $1.5 \%$ to $2.5 \%$. This also proves that the waste of pine fruit and peanut shells from the results of the analysis can already show that the two elements of the raw materials used have met the requirements according to the standards set. Although the material used is not pure coal, it can meet the standard criteria set.

\subsection{Effect of Treatment Composition on Ash Content}

Analysis of ash content was carried out to determine the number of parts that were not burned after complete combustion. High ash content can complicate the operation and maintenance of the combustion equipment.

Ash is the remaining part of the combustion, in this case the ash in question is the ash from the combustion of briquettes. One of the constituents of ash is silica, which has a poor effect on the calorific value of the resulting briquettes.

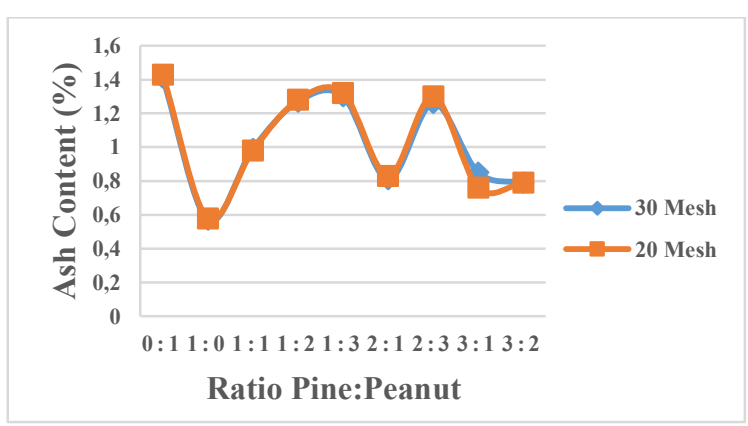

Fig. 2. Relationship between Comparison of Materials with Ash Content (\%)

From Figure 2. it can be seen that the analysis of the ash content in the resulting briquettes all meet the standards set by SNI 4931:2010 which is 20\% both class $\mathrm{A}$ and class B in each briquette. Because all the results of the briquette research show a range of $1 \%$ to $2 \%$ which is of course below the set standard, which is $20 \%$ for each briquette produced.

This is also due to the large quantity of raw material from peanut shells from pine fruit waste, while briquettes with a mixed quantity of pine fruit waste raw materials have a much better ash content and meet the standards set. This also proves that the ash content of peanut shells is higher than that of pine fruit waste.

\subsection{Effect of Treatment Composition on Calorific Value}

Calorific value analysis was carried out to determine the calorific value contained in each briquette. The calorific value is a value that expresses the amount of heat contained in the fuel. The calorific value is the main quality for a fuel. The calorific value was measured using a Bomb Calorimeter. The calorific value greatly determines the quality of the briquettes. The higher the calorific value, the better the quality of the briquettes produced.

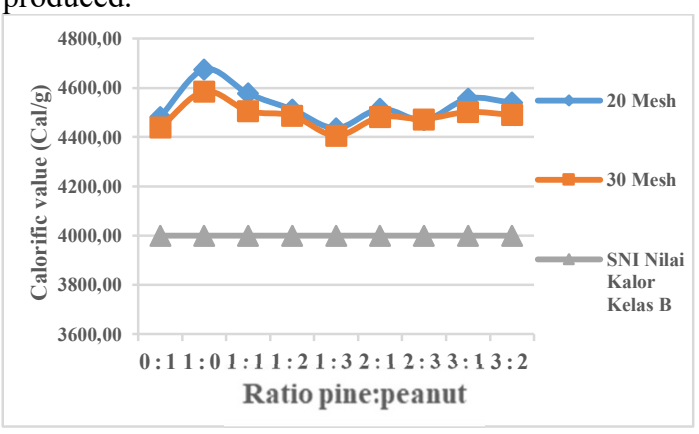

Fig. 3. Relationship between Comparison of Materials with Calorific Value (Kal/g)

From Figure 3. it can be shown that the calorific value resulting from this research is included in the provisions of SNI 4931:2010 regarding classification, quality requirements and testing methods. The calorific value contained in the research briquettes is divided into two categories, namely class A category and class B category. 
For class A category is $5000-6000 \mathrm{cal} / \mathrm{g}$, while for class B category is $4000-5000 \mathrm{cal} / \mathrm{g}$.

For briquettes with a mixture of raw materials of pine fruit waste and peanut shells in a ratio of $0: 1,1: 0,1: 1,1: 2$, $1: 3,2: 1,2: 3,3: 1,3: 2$ for 20 mesh and 30 mesh, all of them are in the class $B$ category which has a calorific value of more than $4000 \mathrm{cal} / \mathrm{g}$. This is because briquettes are included in the class B category, there is a mixture of raw material for pine fruit waste more than peanut shells so that it has a calorific value of more than $4000 \mathrm{cal} / \mathrm{g}$.

As for the class A category, none of the comparisons has a calorific value of more than $5000 \mathrm{cal} / \mathrm{g}$. This is because the determination of the adhesive also affects because in this study the adhesive was $40 \%$ of the total briquette dough or as much as 60 gr. Adhesive variations in the composition of briquettes are needed so that the calorific value produced is in accordance with SNI [7].

\subsection{Effect of Treatment Composition on Compressive Strength}

Compressive strength analysis was carried out to determine the strength of the briquettes to withstand the load. The load is expressed in a certain pressure. The value of compressive strength needs to be known because it is related to the way of transporting and storing briquettes. Briquettes with low compressive strength values tend to crack or break during transportation and storage. Reading the load scale on the marshall compression machine.

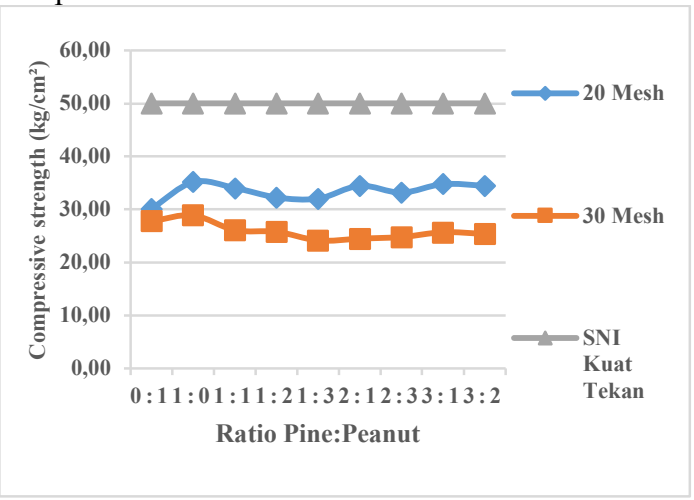

Fig. 4. Relationship between Material Comparison with Compressive Strength $\left(\mathrm{Kg} / \mathrm{cm}^{2}\right)$

From Figure 4. it can be shown that the compressive strength value of briquettes does not meet SNI 4931:2010 regarding classification, quality requirements and test methods because SNI sets a compressive strength value of $50-60 \mathrm{~kg} / \mathrm{cm}^{2}$. However, of the 18 treatments, there was not one comparison treatment that was in accordance with SNI. Then the treatment is 1:0 for 20 mesh and 30 mesh whose characteristic properties are close to the parameter values in SNI. This shows that the mixture of raw materials for pine fruit waste is more than peanut shells. This proves that the raw material for peanut shells can affect the compressive strength value of the analytical briquettes which can reduce the compressive strength value. However, the other ratio composition of pine to peanut show numbers that are not so far different with briquette with 1:0 ratio. It shows that it is still possible to mix the peanut with pine fruit, to reduce the production cost cheaper than using peanut shell only.

In the analysis of the compressive strength of the briquette products, the compressive strength values are uneven or fluctuating. The dimensions of the briquette products that do not meet the standard for compressive strength analysis are the cause of the uneven compressive strength values. Supposedly for compressive strength analysis, the sample height should be twice the diameter. As for the diameter of $6 \mathrm{~cm}$ briquettes with a height of only $5 \mathrm{~cm}$, the mixture of raw materials used also affects the compressive strength. In addition, the dimensions of the briquettes are not in accordance with the requirements of the compressive strength analysis, there are other factors that influence the analysis of the compressive strength, it is possible that the compressive strength test equipment is not standardized and not calibrated. This also causes the results of the analysis to be less accurate [8].

\section{Conclusions}

1. Waste pine fruit and peanut shells can be used as an alternative fuel in the form of briquettes with the addition of molasses adhesive.

2. The best briquettes from 18 treatments were found in the comparison treatment of pine fruit waste: peanut shells with a ratio of 1:0 (pine fruit waste without peanut shells) had the highest heating value found in a 20 mesh sieve size of $4674.50 \mathrm{cal} / \mathrm{g}$.

3. It can be seen that the waste briquettes of pine fruit and peanut shells with a variation of a 20 mesh sieve is better than a 30 mesh sieve. Because the larger the mesh size used, the better the quality of the briquettes obtained.

\section{References}

1. P. W. Roby, T. Akhir PSTL- FTSP, UPN "Veteran" Jawa Timur (2012).

2. N. Ndraha, T. Akhir, Dep. Tek. Pertanian FP, USU (2009).

3. S. Marulam, T. Akhir, Prodi Kehutanan - FP, Univ. Simalungun Pematangsiantar (2009).

4. B. U. K. Widodo, Analisis Termofisik Kulit Kacang Tanah [Online] http://www.digilib.its.ac.id

5. Muchjidin, Pengendalian Mutu dalam Industri Batu Bara. (Bandung: Institut Teknologi Bandung, 2006).

6. BSN, Briket biobatubara SNI 01-4931-2010 (2010).

7. P. W. P. Yayan, T. Akhir, PSTL - FT, UPN "Veteran" Jawa Timur, (2014).

8. D. P. Ardika, T. Akhir, PSTL - FT, UPN "Veteran" Jawa Timur, (2014). 